\title{
Prototype User Interface Mobile App E-Learning
}

\author{
Henderi $^{1}$, Praditya Aliftiar ${ }^{*^{2}}$, Alwan Hibatullah ${ }^{3}$ \\ ${ }^{1}$ Program Studi Magister Teknik Informatika Universitas Raharja, ${ }^{2}$ Program Studi Sistem \\ informasi Universitas Raharja, ${ }^{3}$ Program Studi Teknik Informatika Universitas Raharja \\ Email : ${ }^{1}$ henderi@ raharja.info, ${ }^{* 2}$ praditya.aliftiar@ raharja.info, \\ 3alwanhibatullah@ raharja.info
}

\begin{abstract}
Abstrak
Teknologi informasi telah berkembang dengan pesat dari waktu ke waktu. Adapun salah satu teknologi yang lumrah dimiliki oleh banyak orang saat ini adalah smartphone dengan platform android dan IOS. Dengan mengetahui faktor ini, para mobile developer saling berlomba untuk merancang aplikasi dengan user interface yang menarik sehingga user tertarik untuk menggunakannya. Pada tahap dalam pengembangan aplikasi mobile, dimulai dari perancangan prototype user interface. Tahap ini bertujuan untuk memvisualisasikan kebutuhan user, meningkatkan pengalaman pengguna dan mempermudah proses coding oleh programmer. Dalam penelitian ini, peneliti menerapkan metode prototype. Penelitian ini menghasilkan sebuah rancangan prototype user interface aplikasi e-learning yang terdiri dari high fidelity prototype.
\end{abstract}

Kata kunci : prototype, user interface, aplikasi mobile, e-learning

\begin{abstract}
Information technology has developed rapidly from time to time. One of the technologies commonly owned by many people today is smartphones with the Android and IOS platforms. By knowing this factor, mobile developers compete with each other to design applications with attractive user interfaces so that users are interested in using them. At this stage in mobile application development, starting from designing a user interface prototype. This stage aims to visualize user needs, improve user experience and simplify the coding process by programmers. In this study, researchers applied the prototype method. This research produces a prototype design for the e-learning application user interface which consists of a high fidelity prototype.
\end{abstract}

Keyword : prototype, user interface, mobile app, e-learning

\section{Pendahuluan}

Seiring dengan pesatnya perkembangan teknologi, penggunaan smartphone semakin meningkat. Berdasarkan survey kominfo pada tahun 2017 menunjukan sebanyak 66,3\% masyarakat indonesia yang telah menggunakan smartphone dan sebanyak $45 \%$ masyarakat indonesia menggunakan internet. ${ }^{[1]} \mathrm{Hal}$ ini menunjukan bahwa cukup banyak masyarakat yang menggunakan smartphone dan internet untuk menunjang berbagai kebutuhan. Banyaknya pengguna smartphone membuat para mobile developer saling berlomba untuk merancang aplikasi dengan user interface yang menarik sehingga user tertarik untuk menggunakan aplikasi dan meningkatkan pengalaman pengguna dalam menggunakan aplikasi.

Pada masa dunia yang dilanda pandemi covid-19 seperti sekarang ini, masyarakat harus membatasi segala aktivitas yang menimbulkan keramaian dan mematuhi protokol kesehatan yang ada. Salah satu aktivitas yang dibatasi adalah aktivitas belajar mengajar yang ada di Kampus. Para Mahasiswa tidak diperkenankan untuk mengikuti pembelajaran di Kampus secara tatap muka. Oleh karena itu, melihat dari permasalahan ini peneliti berinisiatif untuk merancang 
suatu prototype aplikasi mobile e-learning yang dapat digunakan oleh Mahasiswa untuk pembelajaran melalui daring. Dengan menggunakan aplikasi ini, Mahasiswa dapat mengakses kelas dimanapun dan kapanpun dengan menggunakan smartphone yang terhubung dengan jaringan internet.

Aplikasi mobile memiliki tampilan antarmuka yang menghubungkan antara user dengan sistem yang disebut dengan user interface. Dalam proses merancang suatu tampilan user interface dimulai dari tahap prototyping dimana berisi gambaran aplikasi yang nantinya akan dikembangkan. Pada penelitian ini proses prototyping menggunakan high fidelity. High fidelity prototype memiliki tingkat presisi tinggi karena sudah memiliki ukuran baik untuk tata letak, font, icon, warna yang digunakan, dan lainnya. Dengan dibuatnya high fidelity prototype diharapkan dapat mempermudah programmer dalam proses coding aplikasi.

\section{Metode Penelitian}

Penulis menggunakan metode prototype dalam merancang user interface, sehingga diperoleh gambaran mengenai aplikasi yang akan dikembangkan. Pada bagian ini terdiri dari 3 langkah yaitu :

a. Pengumpulan kebutuhan

Di tahap ini peneliti mengumpulkan data yang terdiri dari kebutuhan user agar prototype yang dibuat sesuai dan berjalan dengan baik.

b. Merancang prototype

Di tahap ini, dibuat rancangan prototype user interface sesuai dengan kebutuhan. Rancangan ini meliputi high fidelity prototype.

c. Evaluasi

Di tahap ini peneliti melakukan evaluasi dan pengujian terdahap prototype yang dirancang peneliti.

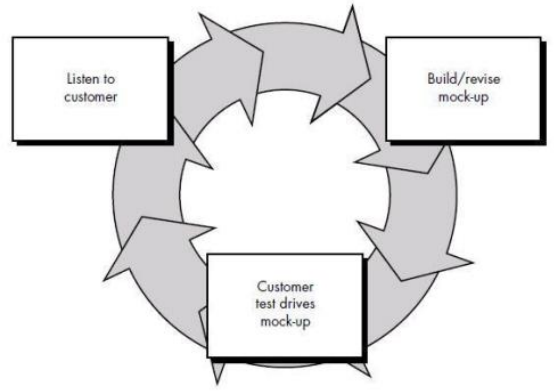

Gambar 1. Metode Prototype

\section{Literature Review}

Berikut ini adalah penelitian yang telah dilakukan dan searah dengan topik yang akan dibahas pada jurnal ini, yaitu sebagai berikut:

1. Penelitian yang dilakukan oleh Aris Martono, Padeli, dan Rosalina Miliartha mengenai "Rancang Bangun Aplikasi Sistem Diskusi Pembelajaran Online Pada Perguruan Tinggi". Permasalahan yang dibahas yaitu perkembangan diskusi pembelajaran untuk kelas reguler pada perguruan tinggi raharja kurang berkembang, sehingga dibuatlah sebuah wadah untuk diskusi pembelajaran, sehingga memudahkan proses pembelajaran diluar perkuliahan. Untuk pengumpulan data pada penelitian ini dilakukan dengan 
wawancara dan observasi, serta menggunakan metode $U M L$ dalam melakukan pemodelan sistem $^{[2]}$

2. Penelitian yang dilakukan oleh Atnis Kurnia Rianingtyas dan Kartika Kusuma Wardani mengenai "Perancangan User interface Aplikasi Mobile Sebagai Media Promosi Digital UMKM Tour and Travel". Permasalahan yang dibahas yaitu persaingan usaha dalam lingkup bidang tour dan travel yang dikuasai oleh travel skala besar, sehingga usaha skala UMKM membutuhkan media dalam bentuk digital untuk mempromosikan jasanya kepada para wisatawan. Pada penelitian ini digunakan metode deep interview dalam mengumpulkan kebutuhan user. Penelitian ini bertujuan untuk menghasilkan rancangan prototype user interface aplikasi mobile yang sesuai dengan rancangan user experience $^{.[3]}$

3. Penelitian yang dilakukan oleh Syifa Fauzia, Fenty Eka Muzayyana Agustin, Undang Syaripudin dan Yuditha Ichsani mengenai "Perancangan Prototype Tampilan Antarmuka Pengguna Aplikasi Web Kamardagang.com Dengan Teknik Flat Design Pada PT. Selaras Utama Internasional". Permasalahan yang dibahas yaitu user interface pada web kamardagang.com yang masih sederhana sehingga membuat web kurang user friendly. Pada penelitian ini menggunakan teknik flat design dalam merancang prototype, sehingga tampilan web lebih minimalis dan menekankan pada sisi fungsionalitas. Penelitian ini bertujuan untuk menghasilkan rancangan prototype user interface website kamardagang.com yang minimalis, user friendly, dan memudahkan para front-end developer pada saat penerapan desain prototype ke dalam aplikasi ${ }^{[4]}$

4. Penelitian yang dilakukan oleh Diky Wardhani dan Akhmad Pandhu Wijaya mengenai "Perancangan Prototype User interface Aplikasi Mobile Sistem Informasi Akademik Institut Teknologi dan Bisnis Bank Rakyat Indonesia". Permasalahan yang dibahas yaitu BRI Institute sebagai pemain baru dalam dunia pendidikan, mencoba memanfaatkan teknologi informasi untuk menunjang kegiatan operasional yaitu sistem informasi akademik. Pada penelitian ini menggunakan metode prototype sehingga user dapat memberikan masukan terkait fitur-fitur pada aplikasi. Penelitian ini bertujuan untuk memudahkan developer pada saat mengembangkan aplikasi dan meningkatkan user experience saat menggunakan aplikasi. Hasil dari penelitian ini yaitu prototipe antarmuka login, halaman menu, dan halaman perkuliahan.

5. Penelitian yang dilakukan oleh Moh Dani Ariawan, Agung Triayudi dan Ira Diana Sholihati mengenai "Perancangan User Interface Design dan User Experience Mobile Responsive Pada Website Perusahaan". Permasalahan yang dibahas adalah Pada website direktorat jenderal ketenagalistrikan masih kurang user friendly, dikarenakan tampilan website yang kurang menarik dan belum responsive saat diakses melalui perangkat smartphone. Pada penelitian ini menggunakan metode $H C D$ sehingga berfokus pada pengguna. Penelitian ini bertujuan untuk menerapkan aspek $U I$ dan $U X$ lebih nyaman saat mengakses web.

6. Penelitian yang dilakukan oleh Malik Abdul Aziz, Hanifah Muslimah Az-Zahra, Lutfi Fanami mengenai "Evaluasi dan Perancangan User interface Aplikasi Mobile Layanan Pengaduan Masyarakat Online Menggunakan Human Centered Design". Permasalahan yang dibahas yaitu mengevaluasi kualitas user interface pada aplikasi RAPOR dan Qlue. Penelitian ini menggunakan metode pengujian usability testing yang didukung dengan kuesioner USE dan juga metode Human Centered Design. Tujuan penelitian ini yaitu untuk mengevaluasi dan menghasilkan rekomendasi rancangan user interface yang lebih baik. 
3. Hasil Dan Pembahasan

\subsection{Use Case Diagram Mobile App E-learning}

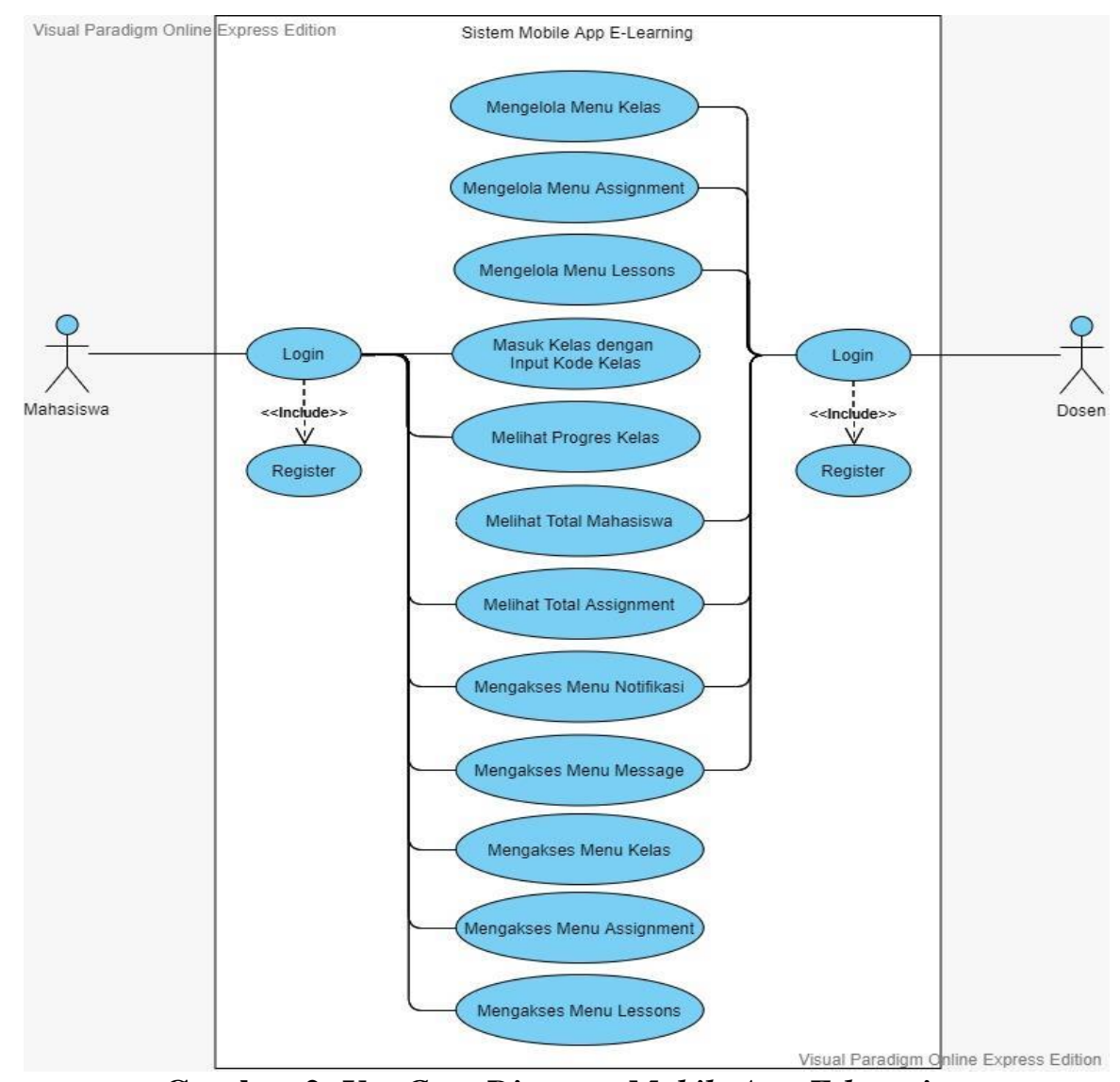

Gambar 2. Use Case Diagram Mobile App E-learning

Berdasarkan gambar 2 use case diagram di atas, dapat dijabarkan :

a. 1 sistem yang mencakup kegiatan secara keseluruhan pada mobile app e-learning.

b. 2 actor yang melakukan kegiatan yaitu Dosen dan Mahasiswa.

c. 16 use case yang dilakukan oleh actor tersebut. 


\subsection{Flowchart Mobile App E-learning}

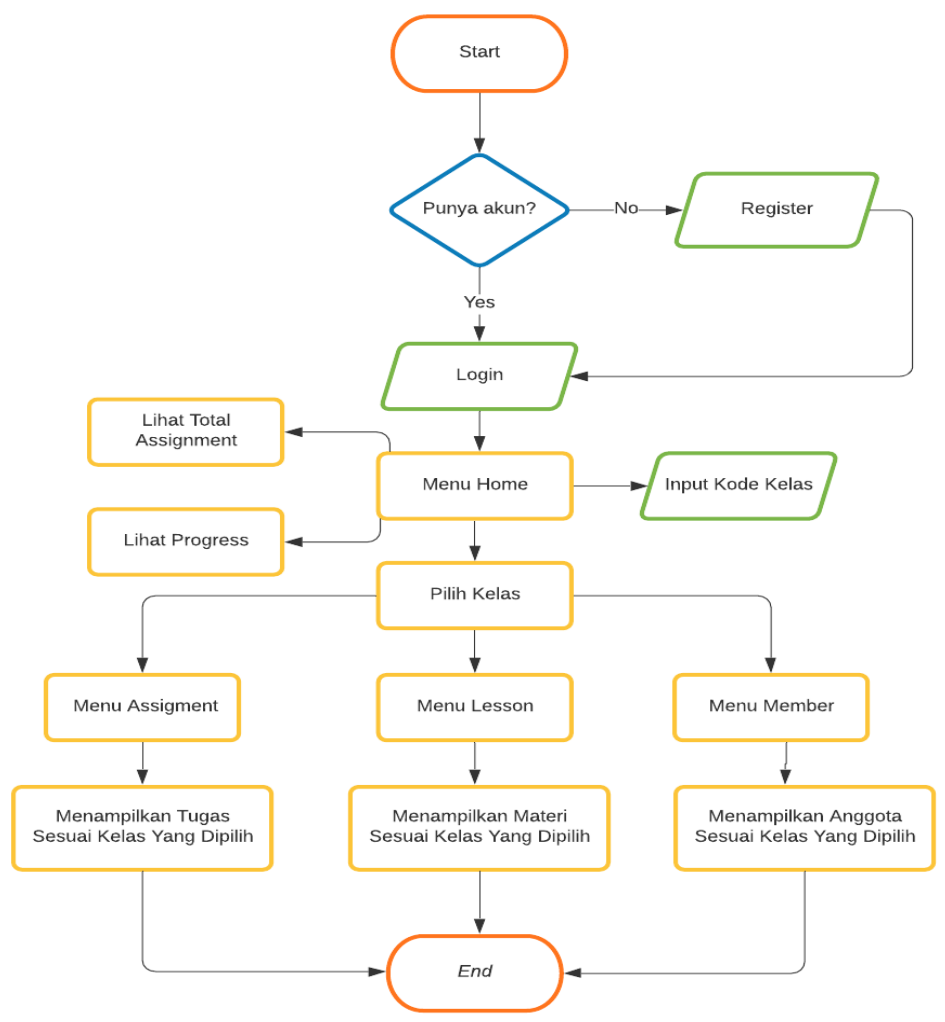

Gambar 3. Flowchart Mobile App E-learning

Pada gambar 3 flowchart menjelaskan alur tentang penggunaan mobile app e-learning. Apabila user sudah mendaftar dan memiliki akun, user dapat langsung melakukan login ke dalam aplikasi, namun jika belum memiliki akun maka user harus register terlebih dahulu. Saat user berhasil melakukan login maka langsung diarahkan ke menu home.

Pada menu home, user dapat melihat progress yang telah berjalan, total assignment, user juga dapat menginput kode kelas jika ingin bergabung dengan kelas yang diinginkan, serta dapat melihat beberapa kelas yang sudah diikuti oleh user.

Saat user mengklik salah satu dari beberapa kelas yang sudah diikuti, maka akan ditampilkan beberapa menu diantaranya yaitu menu assignment, menu lesson dan menu member. Pada menu assignment, user dapat melihat tugas yang telah diberikan oleh dosen. Serta pada menu lesson, user dapat melihat materi yang ada pada kelas tersebut, dan pada menu member, user dapat melihat anggota kelas yang terdiri dari dosen dan mahasiswa yang ada pada kelas tersebut.

\subsection{High Fidelity Prototype}

High fidelity Prototoype memiliki tingkat presisi design yang tinggi karena sudah memiliki ukuran pada tata letak, font, icon, gambar, warna yang digunakan, dan lainnya. Pada tahap ini dirancang menggunakan software figma. Berikut adalah rancangan high fidelity user interface mobile app e-learning: 
a. Halaman Login

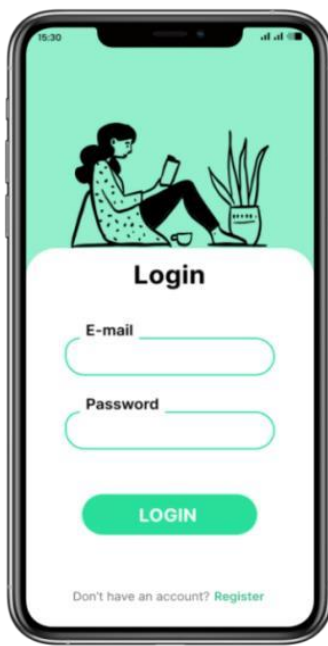

\section{Gambar 4. Tampilan Halaman Login}

Pada gambar 4 halaman login terdapat terdapat beberapa elemen yang ada pada user interface, yaitu foto ilustrasi, input e-mail dan password, login button untuk masuk ke dalam aplikasi dan jika user belum memiliki akun, user diharuskan untuk daftar terlebih dahulu melalui link register pada bagian bawah.

b. Halaman Register

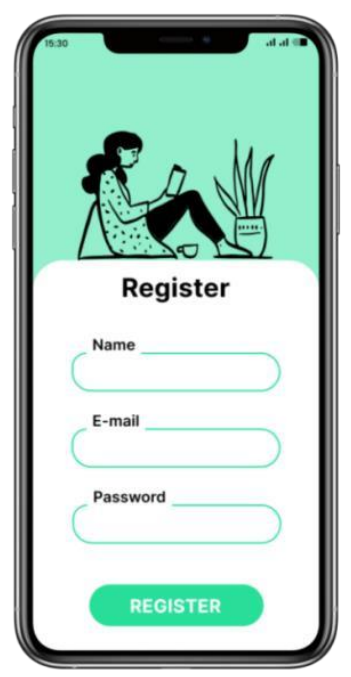

\section{Gambar 5. Tampilan Halaman Register}

Pada gambar 5 halaman register terdapat elemen-elemen yang ada pada user interface, yaitu foto ilustrasi, input nama, e-mail dan password. Serta terdapat register button pada bagian bawah. 
c. Halaman Home

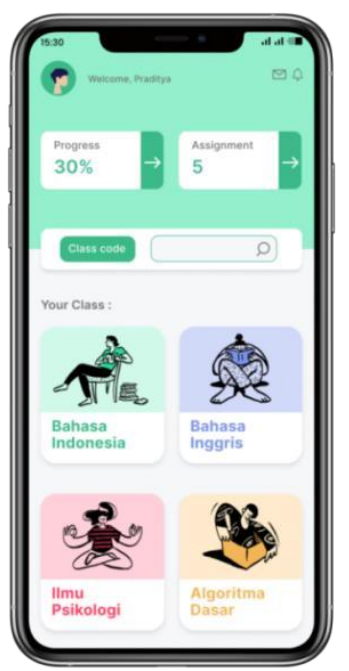

\section{Gambar 6. Tampilan Halaman Home}

Pada gambar 6 halaman home terdapat beberapa elemen yang ada pada user interface yaitu dashboard yang berisi progress dan total assignment. Serta terdapat search bar untuk menginput kode kelas. Pada bagian bawah terdapat elemen card yang berisi foto ilustrasi dan nama kelas.

d. Halaman Assignment

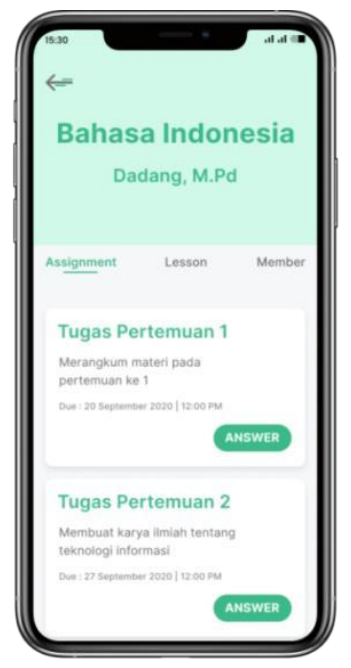

Gambar 7. Tampilan Halaman Assignment

Pada gambar 7 halaman assignment terdapat beberapa elemen yang ada pada user interface yaitu nama kelas, nama dosen, 3 navigasi bar yaitu assignment, lesson dan member. Serta terdapat elemen card yang berisi informasi tugas, dan deadline tugas yang telah diberikan oleh Dosen. 
e. Halaman Lesson

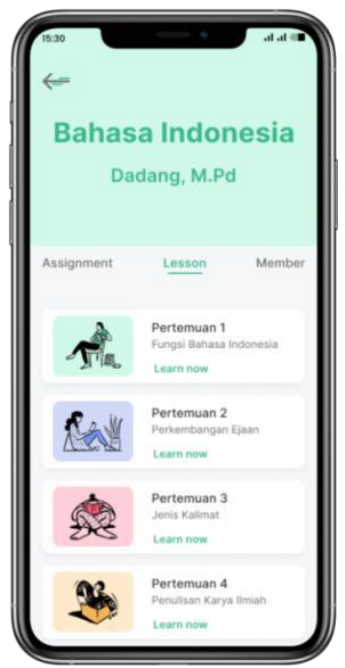

\section{Gambar 8. Tampilan Halaman Lesson}

Pada gambar 8 halaman lesson terdapat beberapa elemen yang ada pada user interface yaitu nama kelas, nama dosen, navigasi yang terdiri dari assignment, lesson dan member, serta card yang berisi foto ilustrasi, pertemuan, deskripsi materi, serta text learn now untuk mengakses materi.

\section{f. Halaman Member}

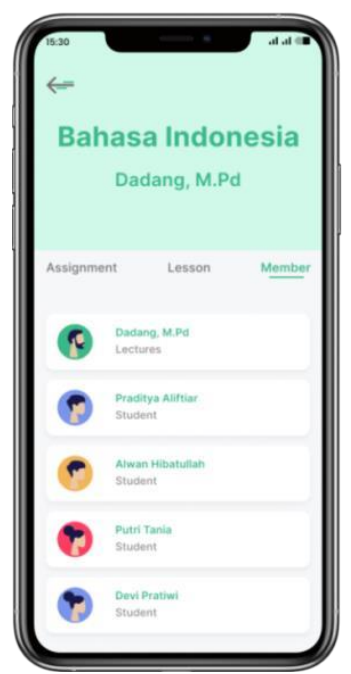

Gambar 9. Tampilan Halaman Member

Pada gambar 9 halaman member terdapat beberapa elemen yang ada pada user interface yaitu nama kelas, nama dosen, navigasi yang terdiri dari assignment, lesson dan member, serta card yang berisi foto user, nama user dan status user.

\subsection{Pengujian Prototype}

- Pada langkah ke 4, semua user cukup lancar berada di menu assignment.

- Pada langkah ke 5, semua user cukup lancar berada di menu lesson. Pada langkah ke 6, semua user cukup lancar berada di menu member.

- Dari keempat user tidak ditemukan user yang bingung pada saat berada di

- $\quad$ langkah $1 \mathrm{~s} / \mathrm{d}$ langkah 6. 


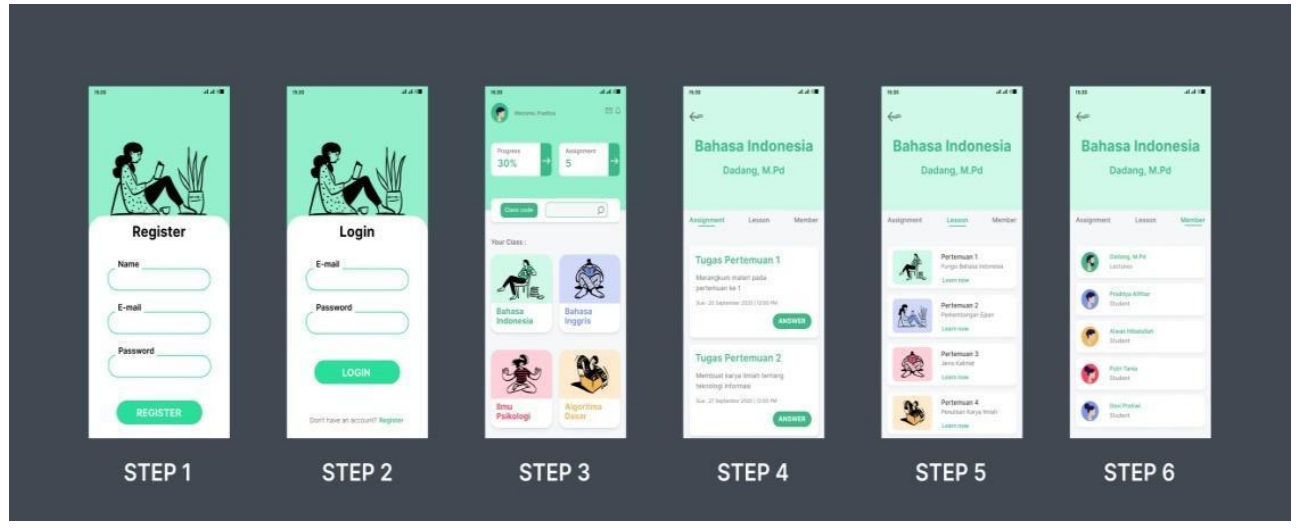

Gambar 10. Skenario Test

Pada gambar 10 tahap pengujian dibuat skenario yang berisi step 1 sampai 6 . Tujuannya yaitu untuk memandu user dalam melakukan tes. Pada step 1 user diarahkan ke tampilan register, step 2 menu login, step 3 menu home, step 4 menu assignment, step 5 menu lesson dan step 6 menu member. Hasil pengujian kemudian akan dicatat kedalam tabel hasil dari evaluasi atau pengujian.

Tabel 1. Tabel Hasil Pengujian

\begin{tabular}{|c|c|c|c|c|c|c|}
\hline USER & STEP 1 & STEP 2 & STEP 3 & STEP 4 & STEP 5 & STEP 6 \\
\hline USER 1 & & & & & & \\
\hline USER 2 & & & & & \\
\hline USER 3 & & & & & & \\
\hline USER 4 & & & & & & \\
\hline
\end{tabular}

Lancar

Kurang Lancar

Stop

Berdasarkan tabel 1 hasil pengujian, maka didapatkan hasil sebagai berikut :

- Pada langkah ke 1 , semua user cukup lancar berada di menu register.

- Pada langkah ke 2, semua user cukup lancar berada di menu login.

- Pada langkah ke 3, user 1 dan 3 kurang lancar berada di menu utama. Sementara user 2 dan 4 cukup lancar berada di menu utama.

\section{Kesimpulan}

Berdasarkan penjelasan yang telah dijabarkan pada penelitian ini, maka peneliti dapat menarik kesimpulan sebagai berikut :

1. Prototype dirancang dengan metode high fidelity sehingga dapat menjadi acuan programmer dalam proses coding aplikasi 
2. Dari hasil pengujian dengan 6 skenario dan 4 user, didapatkan hasil bahwa prototype yang telah dirancang dapat dipahami oleh user dengan baik.

\section{Saran}

Dalam pengembangan selanjutnya, terdapat beberapa saran yang dapat menjadi evaluasi dan masukan, yaitu :

1. Penambahan fitur video conference pada setiap kelas, sehingga Mahasiswa dan Dosen dapat bertatap muka secara daring.

2. Pengembangan prototype menjadi aplikasi mobile yang dirancang dengan framework maupun native.

\section{Daftar Pustaka}

[1] Kominfo. Survey Penggunaan TIK. 2017. Jakarta : Pusat Penelitian dan Pengembangan Aplikasi Informatika dan Informasi dan Komunikasi Publik Badan Penelitian dan Pengembangan Sumber Daya Manusia Kementerian Komunikasi dan Informatika Republik Indonesia.

[2] Martono, Aris., Padeli dan Rosalina Miliartha. 2016. Rancang Bangun Aplikasi Sistem Diskusi Pembelajaran Online Pada Perguruan Tinggi. Tangerang: Jurnal CCIT. Vol. 9, No. 3.

[3] Rianingtyas, Atnis Kurnia dan Kartika Kusuma Wardani. 2018. Perancangan User interface Aplikasi Mobile Sebagai Media Promosi Digital UMKM Tour and Travel. Surabaya: Jurnal SAINS DAN SENI ITS. Vol. 7, No. 2. ISSN : 2337-3520.

[4] Fauzia, Syifa., Fenty Eka Muzayyana Agustin, Undang Syaripudin dan Yuditha Ichsani. 2016. Perancangan Prototype Tampilan Antarmuka Pengguna Aplikasi Web Kamardagang.com Dengan Teknik Flat Design Pada PT. Selaras Utama Internasional. Jakarta: Jurnal Teknik Informatika. Vol. 9, No. 2, Oktober 2016. ISSN : 1979-1960.I

[5] Wardhani, Diky dan Akhmad Pandhu Wijaya. 2020. Perancangan Prototype User interface Aplikasi Mobile Sistem Informasi Akademik Institut Teknologi dan Bisnis Bank Rakyat Indonesia. Jurnal BRI Tech Vol. 1, No. 2, Januari 2020. ISSN : 2686-6021.

[6] Ariawan, Moh Dani., Agung Triayudi dan Ira Diana Sholihati. 2020. Perancangan User interface Design dan User Experience Mobile Responsive Pada Website Perusahaan. Medan: Jurnal Media Informatika Budidarma. Vol. 4, No. 1, Januari 2020. ISSN : 2614-5278.

[7] Aziz, Malik Abdul., Hanifah Muslimah Az-Zahra dan Lutfi Fanami. 2019. Evaluasi dan Perancangan User interface Aplikasi Mobile Layanan Pengaduan Masyarakat Online Menggunakan Human Centered Design. Malang: Jurnal Pengembangan Teknologi Informasi dan Ilmu Komputer. Vol. 3, No. 1, Januari 2019. ISSN : 2548-964. 